\title{
狩野川水害に和ける農業被害の構造
}

\section{石 \#素介}

摘要 日本の水害における農業被害の現われかたは。その地域の農業の生産力構造之不可分の関係をもつ。すなわ ち被害主体のもつ社会的性格は，そのおかれた地域的諸条件のもとで、洪水という自然力に対決し，これを克服する 過程を媒介としつつ, 被害の形態と梁さを窮極的に規定するのであつて, 被害の社会的本質は, このような具体的過 程の中ではじめて構造的に把握される。ここでは商品生産の比粉的発達した狩野川流域における農業被害の構造につ いて, 上中下流の標本 4 集落を対象とする実態調查資料によつて分析検討した. 被害の主要な形態は耕地の流失埋没 で, その量・質的程度は上下流で大きな地域差を示す。しかしそれが農業経営に及ぼす打撃は、小農経営層から賃労 働兼業層への転落という形を中心に, 各集落共通して一定の階層的傾向を示し, それがまた災害からの復興過程をも 支配している。つまり被害祳業構造の弱点に集中し，階層差を拡大強化する方向に作用しているので㐫るが，その 具体的な現われかたは地域によつて異り, 商業的農業の発達, とくに農業生産力の担当者たる農民層の成長の如何が 被害構造の規定要因であることを示している.

1. 調査の目的と方法 狩野川水害は規模こそあ まり大きくないが，その烈しさにおいては有数のも ので，被害の形態は多岐にわたり，しかもこの地域 の農業は商品生産の多角的な発展を見せているので， 農業被害の現われかたも，複雑多㥞な性格をもつも のと思われる.そこで農業の受けた被害の打撃の深 さとその影響を，できるだけ深く堀り下げて見るた め，若干の代表集落について主題の調査を行つた。 調査対象”は比較的専業的な色彩の濃い農業集落の 中から，上中下流における被害の性格を考慮して4 力集落を選び，各集落から無作為に大小約 20 戸ず つ合計 71 戸の農家を抽出して聞取り調査を行つた33.

\section{II. 被害の諸形態}

狩野川水害に見られるひとつの特徴は，洪水の破 壊的作用を直接受けた耕地被害が多いことである. なかでも，流失・埋没型の耕地被害は，当年の作物 の損傷ばかりでなく，復旧には改めて造田するのに 近い作業を必要とする.これに対して泥土流入・冠 水型の被害では，堆積土の土質如何によつては，か 小地力若返えりの効果をも期待し得るのであつ て，被害者にとつては前者はとくに深刻な性質をも
つている・耕地被害には明膫な地域差が見られる (第 1 表).すなわち上流部 J 集落ではわさび田の 75\%がやられているが，普通田畑の被害は少く，O 集落では，水田被害が $60 \%$ 以上に及ふ. 中流部 S 集落は，破堤地点という特殊な立地によつて，田畑 ともに高率（約 90\%）の被害を示すが，流失は少な く，埋没の比重が高い.同じ埋没でも，上流が巨岩 石礫の堆積であるのに対して，ここでの堆積物はほ とんど砂である、下流部N集落では，耕地被害の総 比率は水田で 100\%，耕地合計で $81 \%$ と高いが，被 害程度を考慮した換算被害率は $35 \%$ と大巾に低下 する．全体として埋没型の被害が多いことが，注目 される.

家屋被害は集落の立地をすなおに反映して，上流 部の J・O両集落では被害埬数が少なく，中下流 2 集落はほとんど全戸が被害を受けている.ことに破 堤部の $\mathrm{S}$ 集落では大部分が流失するという激しい形 を示すのに反し，N集落は大半が浸水で，両者いち じるしい対照を見せる ${ }^{4)}$. 農機具被害は家屋と運命 をともにしているが，浸水のみのN集落では被㑊農 機具の大部分がすでに修理済みとなつている・家畜

1）本稿は 1959 年度日本地理学会春季大会において発表したものを改訂加篚したものである.

2)

\begin{tabular}{|c|c|c|c|c|c|c|c|c|c|c|}
\hline 符 号 & 町村名 & 集落名 & 農家数 & 調查数 & 水 & 害 & 型 & 舜 & 贯 & 筀 \\
\hline $\mathrm{J}$ & & 地蔵堂 & 59戸 & 21戸 & \multicolumn{3}{|c|}{ 上流漺間わさび田流矢型 } & \multicolumn{3}{|c|}{ わさび尃業経営と従軍的傎労 } \\
\hline $\mathrm{O}$ & 中伊豆町 & 小川 & 71 & 19 & & \multicolumn{3}{|l|}{ 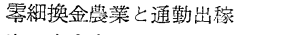 } \\
\hline $\mathrm{S}$ & 大仁町 & 白山堂 & 25 & 19 & & & & \multirow{2}{*}{\multicolumn{3}{|c|}{$\begin{array}{l}\text { 米・まゆ中心の小商品生産 } \\
\text { 商品生産先進地 (米・葑・酪農) }\end{array}$}} \\
\hline $\mathrm{N}$ & 菲山村 & 長 崎 & 46 & 19 & \multicolumn{3}{|c|}{$\begin{array}{l}\text { 中流破堤部集中破壊型 } \\
\text { 下流平坦常習湛水地型 }\end{array}$} & & & \\
\hline
\end{tabular}

3）調查は，1959 年 2 月 17〜19 日，明大地理学研究会員 20 余名の協力を得て実施した。

4）このような被害形態の違いは復旧状況にも直接影響しており，流失・全壊のものは㷋害半年後の冬のさ なかのこの時期にも，大半未復旧のまま天幕や仮小屋生活を続けているのに対して，浸水家屋の方はすで にほとんど復旧済みとなつている。 
第 1 表 耕 地 被害 $の$ 集 落 別 集計 単位 反 (\%)

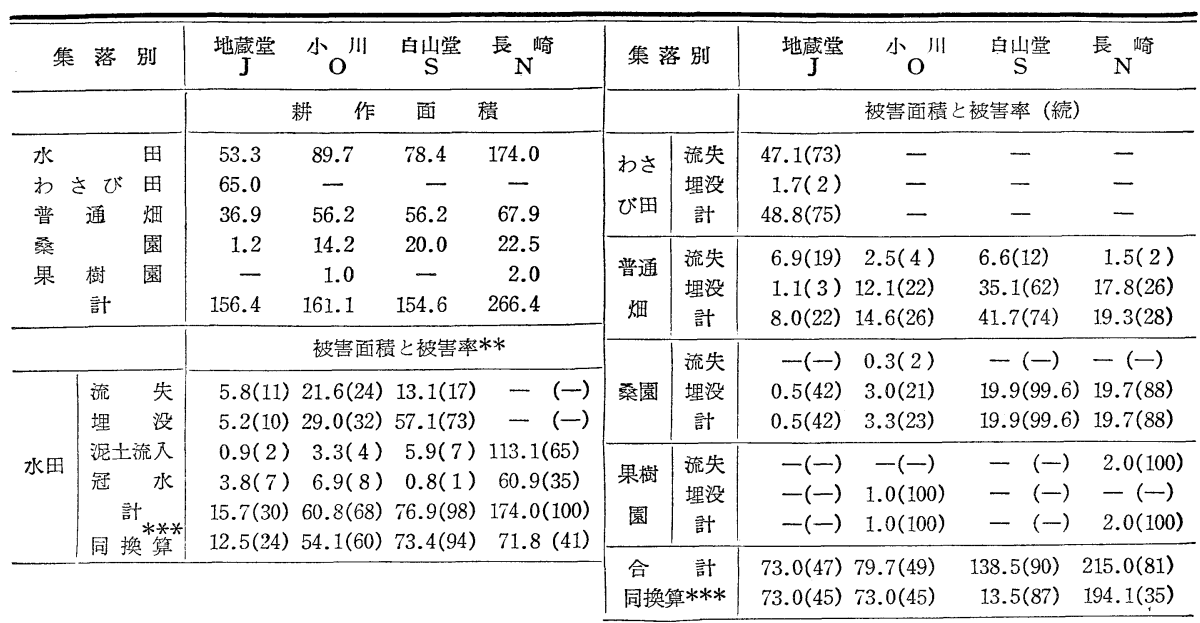

* 本表は調查農家分の集計值で, 白山堂集落の No. 10,19 の 2 農家分は内訳不明のため除いてある.

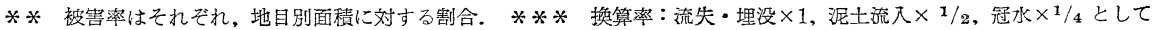
換算，ただし長崎集落の普通畑・桑畑の埋没は泥土流入なみに換算した。

については各集落ともある程度被害回避に成功し， $\mathrm{S}$ 集落で屴大家畜の $40 \%$ を残し， N集落では2階 の床を越す浸水を受けながら同じく $96 \%$ を無事残 している.

\section{III. 農業被害構造の地域别分析}

1) 地蔵堂 $[\mathrm{J}]$

ここは天城山麓わさび産地の 1 中心をなす集落で， 地蔵堂川をさかのぼつた天城国有林地内に, 10 数町 歩の集団わさび栽培地を持ち，集落のほとんどすべ ての農家が専業的あるいは副業的なわさび田経営を 行つている. 本格的專業経営 ${ }^{5}$ と見られる上層 6 戸 は，耕地規模の大ばかりでなく，系譜的には地主層 で，例外なく相当規模の山林所有者でもあるそのの 経営の構造(6) 加見て，この層は農民的というょり
地主的富農の性格を濃厚に持ち，その意味で他の農 民層と区別される.

わさび田以外の普通田畑は，各農家とも $3 \sim 6$ 反 程度を耕作しており，上下層による面積差は見られ ない，農民層の中で，わさび田 1 反未満の雲細な数 戸は，むしろ賃労衝収入7に生活走依存している. こうしてこの集落の農家階層は，A層（地主的富農 の性格をもつわさび田・山林経営)，B層（小農民 的わさび田経営)， C 層 (半プロ的，あるいは身分 的従属性の濃い貧農層) に区分される，貧農層のう ち 1戸（No. 17）は安定した勤務先を持ち，脱農的 傾向を示す点で区別し，D層とするなお，小農的 経営のうち最斗力が弱く，今回の災害によつて半プ 口層に転落の危機に見舞われている層をとくに区別

5）調查農家の経営するわさび田は，最小 7 畧から最大 1 町に及ぶが，かりにわさび田 1 反当り收益の平均 を 13 万円程度（静岡県特産課によるわさび田収益調查の平均值）とすれば大体 4 〜 5 反上の面積を経 営する農家が本格的なわさび田專業経営と言えるであろう.

6）彼等は $3 \sim 6$ 人の常雇を罝きわさび田の補修管理や収穫，山林作業等に彷事させている. 常雇の多くは 同集落内の貧農層で，地主層との間にわさび田普通田畑の貸借関係をもち，屋敷出大り下男の様な従属的 な形で労働提供を行つている.現在では一応日給制の雇傭関係をとつているが，農地改革前は多分に前期 的な身分関係にあつたもののようである.

7）梖労働と言つても，適当な勤務先からの通勤距離を外れているこの山村では，林業労劺，山稼，あるい は地主的富農への従属的な被傏労㗢以外に，雇傭機会はまずない。 
第 2 表 農家構成と災害後の経営の動向 ( $\mathrm{J}$ 集落)

\begin{tabular}{|c|c|c|c|c|c|c|c|c|c|c|c|c|c|c|c|}
\hline \multirow{3}{*}{$\begin{array}{l}\text { 费 } \\
\text { 家 } \\
\text { 番 } \\
\text { 是 }\end{array}$} & \multirow{3}{*}{$\begin{array}{l}\text { 階 } \\
\text { 䍚 } \\
\text { 分 }\end{array}$} & \multirow{3}{*}{$\begin{array}{l}\text { わさ } \\
\text { び田 } \\
\text { 面硈 }\end{array}$} & \multirow{3}{*}{$\begin{array}{l}\text { 経営 } \\
\text { 耕地 } \\
\text { 面積 }\end{array}$} & \multirow{3}{*}{\multicolumn{2}{|c|}{$\begin{array}{l}\text { 所有 啀革前 } \\
\text { 山林 自小作 } \\
\text { 面積 別 }\end{array}$}} & \multicolumn{6}{|c|}{ 災害前後の収入順位の变化 } & \multirow{3}{*}{$\begin{array}{l}\text { 今 後 の } \\
\text { 経営の力向 }\end{array}$} & \multicolumn{3}{|c|}{ 労働力の㕍傭 - 被震関係 } \\
\hline & & & & & & \multicolumn{2}{|r|}{ 位 } & \multicolumn{2}{|c|}{2 值 } & \multicolumn{2}{|c|}{3 位 } & & \multirow{2}{*}{ 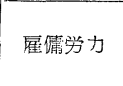 } & \multirow[b]{2}{*}{ 被 侟 } & \multirow[b]{2}{*}{ 関 係 } \\
\hline & & & & & & 前 & 後 & 前 & 後 & 前 & 後 & & & & \\
\hline 1 & A & $\begin{array}{r}\text { 反 } \\
10.0\end{array}$ & 12.9 & $\begin{array}{r}\text { 反 } \\
70^{\circ}\end{array}$ & 地 & わさび & わさび & 米 & 米 & 山 林 & 山 林 & わさび & 常 㕍3人 & な & L \\
\hline 2 & A & $8^{\circ} 4$ & 12.2 & 600.0 & 地 & わさび & わさび & 山 林 & 山 林 & 米 & 米 & わさび & 常 應 5 人 & な & L \\
\hline 3 & A & 8.0 & 11.5 & 500.0 & 0 地 & わさび & 山 林 & 山 林 & わさび & 米 & 米 & わさび山林 & 常 﨎6人 & な & し \\
\hline 4 & $A$ & 5.5 & 9.3 & 55.0 & 地 & わさび & わさび & 山 林 & 山 林 & 米 & 米 & わさび & 常壁 3人 & な & し \\
\hline 5 & A & 5.0 & 11.0 & 150.0 & 地 & わさび & 山 林 & 山 林 & 米 & 米 & & わさび & 延月 70 人 & な & L \\
\hline 6 & A & 4.0 & 8.0 & 130.0 & 9 地 & わさび & 山 林 & 山 林 & 米 & 米 & & 山 林 & 延年 550 人 & な & L \\
\hline 7 & $B$ & 3.5 & 6.8 & - & 自 & わさび & わさび & 米 & 米 & & & わさび & 常赝 1 人 & な & ᄂ \\
\hline 8 & B & 3.4 & 8.4 & 180.0 & ）地 & わさび & わさび & 山 林 & 山 林 & 米 & 米 & 山林 & 常勧 $1 人$ & な & L \\
\hline 9 & $\mathrm{~B}$ & 3.2 & 8.8 & 55.0 & 自小 & わさび & 米 & 米 & わさず & 山 林 & 山 林 & わさび & 常雐 1 人 & な & L \\
\hline 10 & B & 2.9 & 6.9 & - & 自 & わさび & わさび & & & & & わさび & 半年雇 1 人 & な & \\
\hline 11 & B & 2.0 & 7.3 & - & 自 & わさび & & & & & & わさび & 常雇1人+ $a$ & な & L \\
\hline 12 & $\mathrm{~B}$ & 1.5 & 6.2 & - & 地自 & わさび & & & & & & わさび & 臨時雇少数 & 他家手伝 & \\
\hline 13 & $\mathrm{BC}$ & 1.3 & 6.8 & 8.0 & 自小 & わさび & 賃 労 & 椎 茸 & & & & わさび & な & $\begin{array}{l}\text { 土工・遗体収 } \\
\text { 儥労働 }\end{array}$ & 又容に 3 人 \\
\hline 14 & $\mathrm{BC}$ & 1.2 & 7.9 & - & 自 & わさび & 米 & 米 & & & & わさび & な & & \\
\hline 15 & $\mathrm{BC}$ & 1.2 & 4.6 & 10.0 & 自 & わさび & 賃労㗢 & 儥労働 & & & & 賃労働 - 送金 & な & 黍労動 - 出稼 & \\
\hline 16 & $\mathrm{BC}$ & 0.9 & 6.5 & - & 自 & わさび & わさび & 米 & 米 & 黍学衝 & 儥労動 & わさび & な & $\begin{array}{l}\text { 他家わさび田 } \\
\text { 唖 }\end{array}$ & 日復旧賃労 \\
\hline 17 & D & 0.8 & 6.8 & - & 小自 & 勸 務 & 勤 務 & わさび & & & & 乳牛・わさび & な & $\begin{array}{l}\text { 主人保育園勤 } \\
\text { 雇 }\end{array}$ & 加務・妻日 \\
\hline 18 & C & 0.8 & 6.3 & 一 & 自 & 儥労働 & 任労㗢 & わさび & & & & わさび & な & $\begin{array}{l}\text { 他家わさび田 } \\
\text { 働 }\end{array}$ & 日復旧賃労 \\
\hline 19 & $\mathrm{C}$ & 0.7 & 6.4 & 13.0 & 自小 & 倱労働 & 賃労働 & わさび & & いちご & & 貨 労 働 & L & $\begin{array}{l}\text { 他家わさび田 } \\
\text { 動 }\end{array}$ & 日復旧賃労 \\
\hline 20 & C & 0.7 & 1.4 & - & ? & 儥労㗢 & 賃労働 & わさび & & & & & な & & \\
\hline 21 & $\mathrm{C}$ & - & 0.4 & - & 自 & 賃労働 & 稘労墈 & 麦 & 要 & & & 賃 労 働 & な & 大工専業 & \\
\hline
\end{tabular}

して，BC層と名付けることにする8).

ここでの被害はもつぱらわさび田の流失に集中し て現われ，被害面積率に関する限り，階層差はそれ ほど大きくないもつとも被害率は同じでも，上層 は経営面積が大きいのだから残存面積も大きいとい ろことも考慮の要があろうし，C・D層はいずれも 100\%被害だから，これは決定的である.わさび田 が全面的に流失被害を受けたのは，むともとその立 地 ${ }^{9)}$ に関係している. またわさび田被害は，一見と
りかえしのつかぬ深刻な打撃のように思われるが， 実は必ずしもそうではない，築造されたわさび田の 耐用年限はわずかに 10～15 年にすぎないのであつ て ${ }^{10)}$ ，わさび田の流失は明らかに被害には違いない が，半永久的な耐用年限を持つ普通田畑の場合とは 違つて，本来築造後 $10 \sim 15$ 年目に来るべき改築期 日が一挙にやつてきたとを意味するにすぎない、し たがつて経過年数によつて若干の相違はあるが，要 するに未償却部分のみが被害額として計上されるべ

8）本論における階層区分は，各集落ごとに農家の経営規模，その社会的䒺譜，ならびに労働力の再生産の 形態とその社会的性格等を考慮して区分を行つたもので，必ずしも耕地面積規模のみによるものではない。 またとくに被害との関連性を究明するため，災害後の転落層を区別した・いずれも暫定的なものであるが， 被害構造の分析には充分役立ちうるであろう.

9）わさび田の立地は良質豊富な用水と均質な磂層の存在を不可欠の前提とし，したがつて山敝の渓流に沿 つた河原状の土地，または扇状地末端の湧水地等が最も優れた立地条件を示すが，これらはまた同時に水 害に際して最も危険な土地でもある.ところが立地条件の差による㒖かな品質の違いが，敏感に等級差・ 洒格差となつては㸚かえるために，その立地はいやでも沢沿いの危険な場所に接近せざるを得なかつたの である.

10）わさび田の構造は深さ約 $1.5 \mathrm{~m}$ の下層から大小䃯を順次積み上げ，表面には作土として細䃋を整然と敷 き並べたもので，地下水の流動を適度に調節することにこの構造の眼目がある.ところが築造後 10 年以 上経過すると，水の流動に変化を来し，わさびの収量・品質ともに低下しはしめるので，もう一度田床を 崩して基礎から積み直し，老朽化田床の若返りを図らねばならないのである。 
小川 $(0)$ 集落

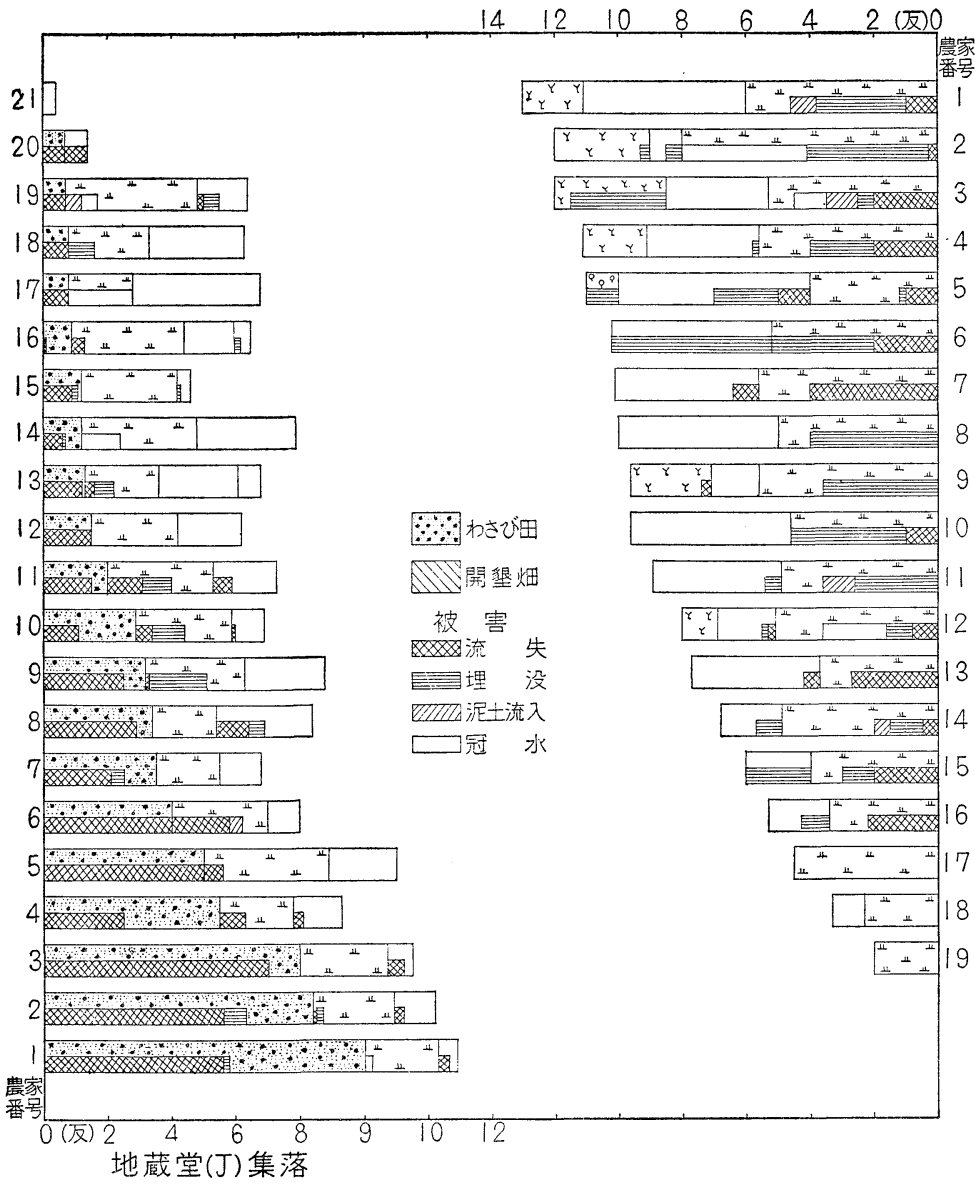

第 1 図（a）集落別・農家別耕地面積とその被害
るという状態へ転落の形勢 にある、C層はもともとか ら賃労働依存の生活で，こ の点変りはないが，わさび 田全滅の打撃は大きく，目 下のところ自分のわさび田 は放亲状態で，他家，主と してA層農家のわさび田復 旧に雇われている。

この集落の場合，表面に 現われた被害形熊を見る限 りでは，上下各階層の間に さほどの違いはないように 見えるが，実質的な被害程 度は，わさび栽培の特殊な 生産力構造に媒介されて, むしろはげしい階層性を带 びている.そしてそれは煚 害復旧の過程においてます ます拡大強化の方向に進ん でいる.

\section{2) 小川 $[\mathrm{O}]$}

ここは大見川すじの中流 部に位置する普通の山間農 村で, 農家は耕地 $5 \sim 13$ 反 を耕作し，僅かの山林を持 つ農家が多い。ここの農家 構成上での 1 つの特色は， 農地改革前の自小作，小作
き筋合いのものであるままたわさび田の改築費の 80\% 以上が労铺費であるが，これは前記の樣な従属 的な常雇を抱えている上層農家にとつては，それほ ど困難な專情ではない11).

このような被害構造の特殊性からも突えるように， $\mathrm{A} ， \mathrm{~B}$ 層農家の大部分はびくともしない強靱さを持 ち，収入源の変化について見ても，わさびと山林収 大が不動の地位を示している.これに対して BC 層 は，いずれはふたたびわさび田経営としての復活を 指向するとしても, 当面賃労働によつて生計を立て
層の一部が農業経営の上では中上層を形成しており， 逆にかつての中小地主層は耕作面積は零細であるが， 若干の山林所有と羑業，それも安定的な教職員勤務 によつて裕福な生活を営み, むしろ脱農的な傾向を 示していることである.ここでは兼業への依存度と その形態力ら，B層（農林業目営的性格の強いも の)，C層（賃労働兼業への依存の性格の強いもの）, およびD層（安定的勤務あるいは自営兼業が生活の 重心をなし，脱農的性格の強いもの）に区分し，B 層のうち儥労働依存への転落層をBC層とした。な

11）事実，調查時において，A・B層農家の多くは国の補助金を待たず，すでに自力でわさび田復旧工事に 着手していた. 
長崎 $(N)$ 集落



第 1 図 （b）集落別農家別耕地面積とその被害
て，若干の階層的傾向を見 ることができる ${ }^{12)}$ ，収入順 位の変化の面（第 3 表）で 顕著なのは，この集落の場 合, 賃労働, それも土木工 事や贸害復旧などの日雇的 賃学働低存への転落層（B C層）が多いことで，災害 後は㱠んど全農家が多少と む，賃金収入に依存してお り，その職種も，工員，事 務員加ら, 日雇, 徒弟, 女 中などの出稼奉公に及び， 一家をあげて賃稼ぎという 農家も6戸 (No. 6，7，9， $10,12,16$ 等いずれも $\mathrm{BC}$ ないしC層）見られる。こ れは，いかにこの集落の小 農経営 ${ }^{13)}$ が基礎の弱いむの であつたかを異書きするも のでこうした脆弱な経営 である故に，被害が奏質的 な被害として深刻化するの である、この点 D A 層の多 くが被害とほとんど無縁の 状態にあるのと全く対照的 である・
おD層のうち山林地主的性格を併せ持つものをD A 層とした・

水田は大見川の氾濫原と支流の沢沿いにあるため， その 6 割が流失埋没被害を受けた（第1図a）. 水 田被害の階層性を検討してみると.19戸中 11 戸(58 \%) は被害率 60～80\%の間にありこここには階層 差は見られないが，被害率 30\%台の 2 戸(No. 5. 14）はB層，無被害の 3 戸 (No. 17，18，19）はD A層，逆に被害率 $100 \%$ の 2 戸 (Nn.6，10）は， いつれも小作出身の $\mathrm{BC}$ 層と $\mathrm{D}$ 層 (馬喰業) であつ

\section{3）白山堂 [S]}

ここは伊豆温泉鄉や大仁，三鼻等の工場地带をす ぐ近傍に控えながら，比較的專業的な色彩の濃い農

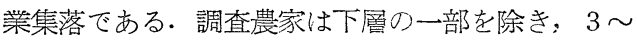
6 反の水田とほぼ同じ位の畑を耕作し，全体として 農家の粒は揃つている，商品作物としては，米のほ か, 養亘, 䓇, 麦, 野菜, 煙草などが入つている. 全体が中間層的で，経営の点から为格別上層農家と 云えるようなとびぬけた農家はみられない，平坦地 でありながら，桑園が多く残り，近傍農村に多い果

12）被害の階層性は家畜動態にも見られる. BC・C層の 2 戸 $($ No. 6,13$)$ は災害後乳牛を手離し, $\mathrm{B} ・ \mathrm{D}$ 層 の 2 戸 (No. 14, 10) は和牛を新規購入している.

13）米作のほか煙草・英等の畑作や酪農，椎茸・木崖等の林産，それに上層の一部に湌是が残るという，雑 多で零細な撸金的商品生産がここでの経営の内容をなす。いずれも家族労働の多投に依存して成立つ部門 が選ばれていることに注意. 
第 3 表農家構成と災害後の経営の動向（O集落）



計 $161.11,033$

第 4 表 農家構成と災害後の経営の動向 ( $\mathrm{S}$ 集落)

\begin{tabular}{|c|c|c|c|c|c|c|c|c|c|c|c|c|c|c|}
\hline \multirow{3}{*}{ 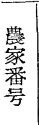 } & \multirow{3}{*}{\multicolumn{3}{|c|}{$\begin{array}{l}\text { 階 経営 所有 燢革前 } \\
\text { 層 耕地 林野 自小作 } \\
\text { 分 } \\
\text { 面積 面積 } \\
\text { 別 }\end{array}$}} & \multicolumn{8}{|c|}{ 竾害前後の収入順位の変化 } & \multirow{3}{*}{$\begin{array}{l}\text { 今 後 } \\
\text { 経営の方向 }\end{array}$} & \multicolumn{2}{|c|}{ 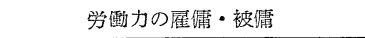 } \\
\hline & & & & 1 & 位 & 2 & 位 & 3 & 位 & 4 & 位 & & \multirow{2}{*}{ 雇礇労力 } & \multirow{2}{*}{ 被 侑 関 係 } \\
\hline & & & & 前 & 後 & 前 & 後 & 前 & 後 & 前 & 後 & & & \\
\hline 1 & B & $\begin{array}{r}\text { 反 } \\
17.5\end{array}$ & $10.0^{\text {反 }}$ 自 & まゆ & 䓦 & 茷 & 麦 & 麦 & まゆ & 野菜 & 野菜 & 米考畜果等 & & \\
\hline 2 & $\mathrm{BC}$ & 13.5 & 一 自小 & & 荫 & & 煙草 & & 米 & & 麦 & 苺, 㖶草中心 & & 農地復旧日雇 3 人 \\
\hline 3 & $\mathrm{BC}$ & 13.2 & 一 自 & 米 & & 薄 & & 麦 & & & & & 年 1 万円 & 错地復旧日雇 2 人 \\
\hline 4 & $\mathrm{BC}$ & 12.0 & 一 小自 & まゆ & 麦 & 麦 & まゆ & 米 & 䔦 & 薄 & 野菜 & & & 厜地復旧日雇 1 人 \\
\hline 5 & & 11.5 & $10.0 ?$ & まゆ & まゆ & 米 & 麦 & 麦 & 米 & 山林 & 野菜 & 米麦野菜 & & 出役労力なし \\
\hline 6 & & 11.3 & 10.0 小自 & 米 & & 莨 & & 野菜 & & 麦 & & 早期復旧 & 年 1.5 万円 & 農地復旧日㕍 3 人 \\
\hline 7 & $\mathrm{BC}$ & 10.5 & 一 小自 & & & & & & & & & 末磪定 & & 慧地復旧日㕍 3 人 \\
\hline 8 & $\mathrm{BC}$ & 10.3 & 一 小自 & 米 & 䓦 & 麦 & 野菜 & 䓅 & & 野菜 & & & & 岾地復旧日雇 1 人 \\
\hline 9 & $\mathrm{BC}$ & 9.5 & 一 自 & 米 & & 夌 & & 野菜 & & まゆ & & 全負死亡・弟跡 & 年 50 人 2 万円 & 出役労力なし \\
\hline 10 & $?$ & 8.6 & 一 自 & & & & & & & & & 子供以外死亡 & & 出役労力なし \\
\hline 11 & $\mathrm{BC}$ & 8.0 & 一 小自 & 米 & 勤務 & 麦 & & & & & & 勤務 & 年 15人 & 勤務 \\
\hline 12 & $\mathrm{BC}$ & 8.0 & － 自小 & 苺 & & 米 & & 野菜 & & 麦 & & 莓・野菜・瀙産 & & \\
\hline 13 & $\mathrm{C}$ & 7.8 & 6.0 自小 & 勤務 & 勤務 & 米 & & 薄 & & 野菜 & & 早晚期・畜産 & 年 10 人 & 勤務 3 人 \\
\hline 14 & $\mathrm{C}$ & 7.2 & 5.0 自小 & 賃労 & 顀労 & 米 & & 麦 & & まゆ & & 飯米磪保 & & 大工 1 人, 農地復旧 1 人 \\
\hline 15 & $\mathrm{D}$ & 5.6 & - ? & 勤務 & 勤務 & 米 & & 麦 & & 苺 & & 土建䳾職 & 年 1.5 万円 & 鴶職 \\
\hline 16 & $\mathrm{BC}$ & 4.1 & 一 小自 & 米 & & 㭧 & & 麦 & & 賃労 & & & & 辳地復旧日咸 2 人 \\
\hline 17 & $\mathrm{D}$ & 3.1 & 一 自 & 勤務 & & 米 & & 薄 & & 麦 & & & & 営鄴 1 人, 勤務 1 人 \\
\hline 18 & $\mathrm{D}$ & 1.5 & $-\quad ?$ & 営業 & & & & & & & & 営業 & & 営業 \\
\hline 19 & $\mathrm{D}$ & 1.1 & 一 小 & 勤務 & & & & & & & & 勤務 & & 勤務 \\
\hline
\end{tabular}

計 164.341 .0

樹や酪農なども入つていないし，耕耘機の利用もあ まり多くないことなどから見て，商業的農業として の発展はそれほど進んでいないようである.階層区 分は他と同様であるが，この集落の場合，被害の特
殊性によつてB層 12 戸のうち 2 戸を残して，他は 全部 B C 層となる.

ここは破堤地点のすぐ近くであるため, 家屋も耕 地も全面的に破壊的被害を蒙つた. その被害は農家 
第 5 表 家族人員被害（S集落）

\begin{tabular}{|c|c|c|c|c|c|c|c|c|c|}
\hline \multirow{2}{*}{$\begin{array}{l}\text { 澽 } \\
\text { 数 }\end{array}$} & \multicolumn{4}{|c|}{ 家族人員の被害 } & \multicolumn{3}{|c|}{ 内 } & \multicolumn{2}{|c|}{ 訳 } \\
\hline & $\begin{array}{l}\text { 死 } \\
\text { 亡 }\end{array}$ & $\begin{array}{l}\text { 重 } \\
\text { 稘 }\end{array}$ & $\begin{array}{l}\text { 無 } \\
\text { 被 } \\
\text { 害 }\end{array}$ & 計 & 夫 & 妻 & $\begin{array}{l}\text { 老 } \\
\text { 人 }\end{array}$ & $\begin{array}{l}\text { 青 } \\
\text { 年 }\end{array}$ & 子 供 \\
\hline 1 & 1 & 1 & 7 & 9 & (1) & (1) & $\langle 1\rangle$ & (1) & {$[1](4)$} \\
\hline 2 & - & - & 8 & 8 & & & & & \\
\hline 3 & - & 1 & 5 & 6 & & & & & \\
\hline 4 & 3 & 1 & 5 & 9 & (1) & [1] & {$[1]$} & $\langle 1\rangle$ & [1](4) \\
\hline 5 & - & - & 4 & 4 & - & (1) & (1) & (1) & (1) \\
\hline 6 & - & 1 & 6 & 7 & (1) & (1) & $\langle 1\rangle(1)$ & - & (3) \\
\hline 7 & - & 1 & 8 & 9 & (1) & $\langle 1\rangle$ & (2) & (1) & (5) \\
\hline 8 & 2 & - & 5 & 7 & [1] & 〔1] & - & (1) & (4) \\
\hline 9 & 5 & - & - & 5 & 〔1] & [1] & - & - & [3] \\
\hline 10 & 6 & - & 4 & 10 & [1] & [1] & 〔1] & {$[1]$} & [2](4) \\
\hline 11 & 2 & - & 2 & 4 & - & 〔1] & - & (1) & [1](1) \\
\hline 12 & 5 & - & 2 & 7 & (1) & (1) & 〔1] & 一 & $\llbracket 4\rfloor$ \\
\hline 13 & - & - & 9 & 9 & & & & & \\
\hline 14 & 6 & - & 3 & 9 & (1) & {$[1]$} & [3] & (1) & {$[2](1)$} \\
\hline 15 & 9 & - & 2 & 11 & (1) & {$[1]$} & 〔2] & [1] (1) & $\lceil 5\rfloor$ \\
\hline 16 & - & - & 5 & 5 & (1) & (1) & - & - & (3) \\
\hline 17 & 5 & 1 & 1 & 7 & (1) & $\langle 1\rangle$ & [1] & {$[1]$} & {$[3]$} \\
\hline 18 & - & - & 8 & 8 & & & & & \\
\hline 19 & 3 & -1 & 3 & 61 & (1) & {$[1]$} & - & [1] & {$[1](2)$} \\
\hline 計 & 47 & 6 & 87 & 140 & & & & & \\
\hline
\end{tabular}

単位は人, 内訳の橍，〔〕は死亡,〈〉は重偪, ○は無被害 (含軽倁)のそれぞれ人数を示す。

を選ばず，階層を閣わずに肢んでいる，狩野川水害 の中でも，ここは熊坂，中島と並んで，りつと被 害激甚地に属するが，その被害のひどさを端的に表 わしているのは人命の損賃である ${ }^{14)}$. 主婦を失つた 家庭が多いので，男やもめ農家では家事労働に困つ て抢り，これがこの集落でいち早く共同欣事所を設 けた直接の契機となつた，経営者が居なくなつた農 家（No.9，10，11) では，他出していた兄弟や青年 を呼び帍して帰農させている．この集落の場合，収 入順位の変化には災害後の傾向的な動きは明確には 表われていない：ここには災害後の現実の状態でな く，むしろこれからの希望が表明されていると見る
べきであろう 15$)$ このことは農地復旧工事への全面 的な出役の状況にも明膫に現われている. しかし何 分にも人員の死傷が多いので，労衝力の減少がここ では大きな問題である. 出役能力の少ない，あるい は全然ない農家はそれだけ苦しいわけで，共同化が 徹底すれば，そうした不均衡もカバーされ得るのだ が，現在のところ共同化といつても，炊事と復旧作 業だけで，耕作や経営の共同化には未だほど遠い状 態にあるので，今後は新しい階層差を生ずる可能性 があると見なければならない，要するにここでは被 害の階層性が潜在的な状態で存在すると云えよう。

\section{4）長崎 [N]}

この集落は低位部水田地带に位置し，耕作規模は 他の 3 集落に比べて格段に大きく，1２町経営の 農家が大部分を占める. 戦後乳牛や薄, 卜マト等商 品作物の導大が急速に進み，現在見られるような多 角的商品生産の態勢を整えた ${ }^{16}$. 酷農は三島・沼津 市場対象の個別出荷であるが，菠は全村的な共同出 荷態勢をとり，綮格な清浄栽培，品質検查を自主的 に励行し，東京市場でも銘柄の地位を確立している。 しかし反面耕耘過程は專ら畜力に依存し，動力耕耘 機はほとんど利用されていないまた経常的に賃労 収入に依存せ柇ばならない半プロ廏に相当する農家 がほとんど見られないこともいまひとつの特徴であ る.

今回の水害に際しては，南条附近の大破堤から直 進した洪水に，柿沢川下流の 3 ケ所の破堤部からの 逆流が加わつて，地上 $3 \sim 4 \mathrm{~m}$ に達する浸水を受け, 田烟とも全面的な，泥土流入，冠水被害を蒙つた17)。 また柿沢川をこえた川向う（函南村地籍）の水田は 冠水のみで泥土も $3 \sim 9 \mathrm{~cm}$ 堆積した程度であつた。 経営水田中，泥土流入田の占好割合を階層別に見

14）調査農家中家族内訳のわかる 15 戸について見ると，家族人員 110 人中 47 人 $43 \%$ が死亡し，ことに老人 と主婦は $70 \%$ 前後の死甥率を示す. 子供の死亡率も $42 \%$ に達し，成年男子の死亡率のみが $20 \sim 30 \%$ と 低いのは，洪水時の奔流の強さを物語つている.

15）調查当時，被害耕地には冬作の作付はほとんど見られず，もちろん食糧の備蓄もないので，もつぱら賃 金収入と援助金品に頼りながら，とりあえずの生活の立て直しを図つているという状態であつた。

16）この村の戦後の農業の動きについては，市岡幸三・川口 諦（1958）：動きつつある村，農業総合研究. 12，1. 189〜224 参照.

17）集落附近の田面には泥土堆積 $30 \mathrm{~cm}$ 前後，排水路に近い低位部は $40 \sim 50 \mathrm{~cm}$ と厚くなつている.なお冠 水田にも堆積皆無ではないが，大体 $10 \mathrm{~cm}$ 前後あるいはそれ以下のものを冠水田とした．調查農家の回答 例によると，水稲の平年作反当収量 3.2 石に対して，泥土流入田では $0 \sim 0.4$ 石，冠水田では $2.0 \sim 2.6$ 石. の収穫となつている. 
第 6 表 農家構成と災害後の経営の動问（N集落）

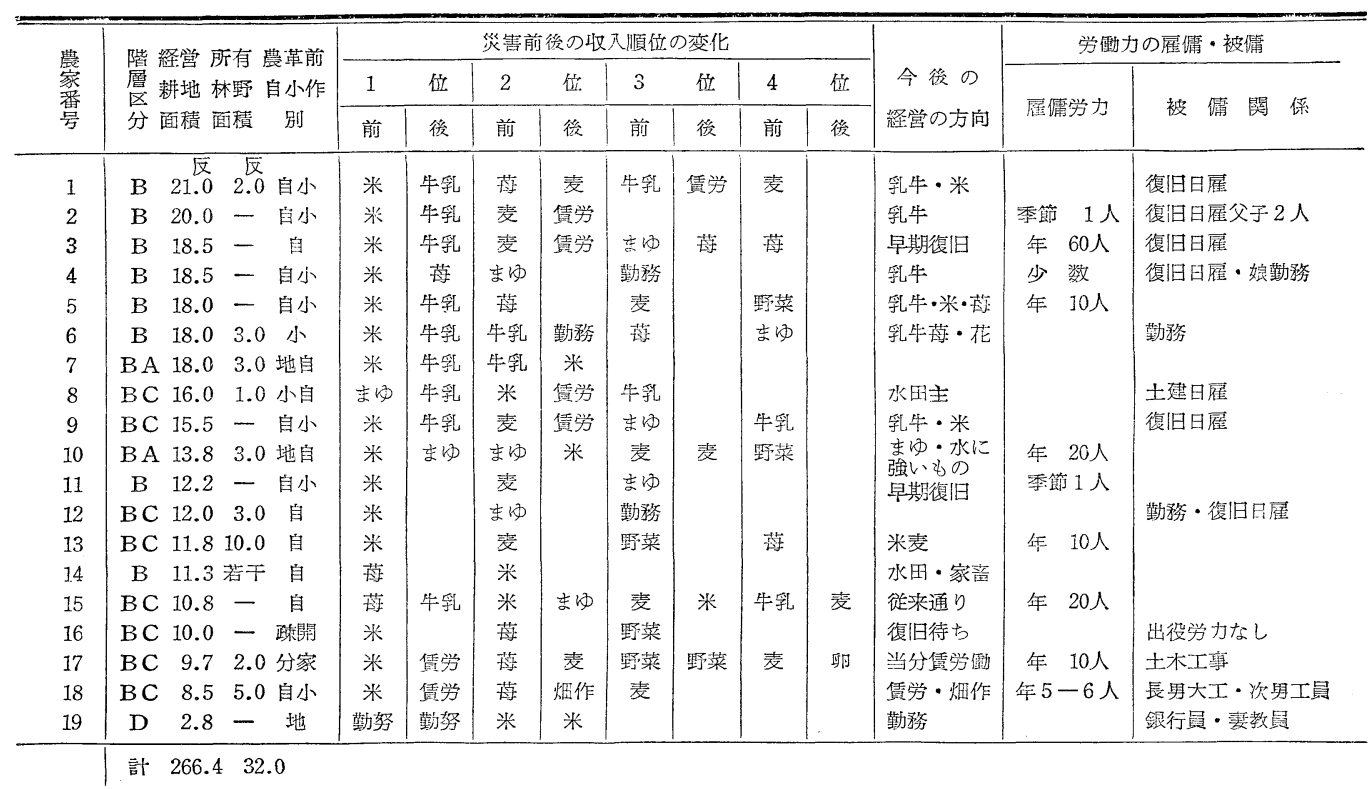

ると全戸平均 65\% に対し，B A層 2 戸は $20 \% ， B$ 層 8 戸は $64 \% ， B C$ 層 8 戸は $83 \% ， D$ 層 100\% と明 瞭な階層性を示す.この結果に見る限り，上層農家 ほど水害安全地を，下層農家ほど低位部の水害危険 地を，相対的により多く耕作しているわけである18)。

ここで注目されるのは，各農家と为近傍平坦部の 耘作以外に，3〜4反の開墾畑を持つていることで ある19). 平地畑の 90\% が埋没しているのに対し， 開飾畑は $3 \%$ の流失被害に留つている点に竾害時の 予備耕作基地としての開笙畑の意義を認めることが 出来る．つまりここでの大きな特色は，農家が水害 に馴れているという点20)，つまり水害への常習水害 地的な対応形態が以前から準備されていて，それが
被害の軽減，克服に少なから奴役割を果しているこ とである.こうした災害への事前処置の効果は，そ のまま災害後の収入面にも反映して，災害前収入の 首位を占めていた米作に代つて，現在では牛乳貶売 による収入が大部分(とくに上層)の農家の主たる支 えとなつている、ついで従来見られなかつた日雇穓 労銜収入が，これまた大多数の農家に沶いて重要な 地位を占めている，収大面でのこの 2 つの顕著な変 化は，やや矛盾した傾向のように見えるが，実はこ の場合の賃労働は，大部分自からの耕地を含む共同 の耕地贸害復旧工事への出役であつて，とくに上層 農家にとつては必ずしも笨迫的な賃稼ぎを意味する ものではない21).したがつて現在賃労働収大依存の

18）この階層性は，具体的には上層農家の中に柿沢川を越えた川向うに田をもつているものが多いことによ るもので，たとえばNo.7 (BA層) は水田の全部，No. 1，4，10，11の各農家はそれぞれ水田の58４4 \%を川向うに持ち，泥土流入を色れている.

19）この開䫀畑は隣村函南村地内にあり，以前は部落共有の採草地であつたものを，数年前各戸に分割，開 恠した山畑で，調查農家の普通畑 6.8 町の内 4.9 町 $(72 \%)$ を占める.

20）農家の物置に小舟が用意されていることもその1例であるが，家畜の避難慣行は実際に効果を発揮した 著るしい例である.水害当日の午後，ここではほとんど全農家が山寄りの隣り集落へ家畜を預けておいた ので被害を危れたのである。ここでは以前加ら緊急時のこうした家畜の預託慣行 (年具米 1 升をつける) が行われているという。

21）しかもこの村の災害復旧は単なる原形復旧でなく，耕地の区画整理，交換分合，道・水路改修を含む全 村的な土地改良事業を兼ねているのであつて，戦前この村の用水幹線の新設工事が実施された際，同時に 一貫して行うべくして果し得な方つた宿題を，災害を契機に「改良復旧」として実施に移したものなので ある。 
状態にある農家でも，その多くは「転落層」と呼ぶ 事が必ずしも妥当とは云えない程度の，一時的な転 落層と判断すべきであろう.

\section{IV. 被害構造につんての総括}

以上の具体的分析の中から導き出されるところを， 災害論の観点から総括すると，以下の諸点が指摘さ れる。

1）洪水の被害への転化の機構 被害の直接的現 象形態は，耕地，家屋，その他の被害等に見られる ように，洪水の上中下流にわたる運動形態とこれに 対するそれぞれの地形的立地条件の違いを強く反映 して現われている.しかし洪水と被害との関連は， それほど単純な直線的な関係ではない，洪水の前に 身をさらしているものがあるからこそ，破壊成生ず るのであつて，洪水を受ける側のありかたを同時に 問題としなければ，その関係を明らかにすることは できないであろう．その点では，今回の水害の笲 の中だけでも，多くの事実を挙げることが出来る. 山間部で洪水の危険の大きい氾濫原にまで耕地が進 出し，そうした所が多く被害を受けているのは珍ら しい例ではない.わさび田の場合は，田床の耐用年 限が短いという特殊な事情を媒介として，むしろは じめから洪水の危険を承知の上で，生産を行つてい たのであつて，これは破壊即被害とはならない顕著 な例である，橋梁や用水堐などの河川構築物のため に，またそれに流木等の人工物が加つて，洪水の運 動が恋形され，その破壊力を増大したことも，すで に周知の事実となつている22).これらの諸事実は， つまり，人間が与えられた自然を開発し利用して行 く過程で, 本来的な自然の力, 自然史の運動法則に 対する認識を誤り，自然の酷使に走つたところに災 害が生れるという，災害の基本的論理を物語つてい る.

2）被害の深化和よび克服の諸条件 ひとたび発 生した被害が，どのような打撃，影響をもたらし，
またそれがどのようにして克服されて行くかという ことは，当然その被害を受けとめる例の主体的，客 体的条件の如何に関わることである. 農業被害を問 題とする場合, それが被害地域の農業の社会的樍造 のもつとも弱い環に，集中的に発現していることは まぎれもない事帇である・調査集落の農家被害を階 層的に総括すると，地主的系譜を持ち，多少とも， 地主的性格を蔵する階層（A，DA，BA 層）はほと んど例外なく優良地の独占その他の事情によつて， 被害を回避あるいは難なく克服している．また農業 以外に自営あるいは安定的勤務康業を持つ階層（D 層）にとつても，人命，家屋さえやられなければ， 被害はほとんど打撃とはなつていない，ところが同 じ兼業農家であつても，不安定な賃稼ぎに依存する 半プロ的兼業農家階層（C層）の場合は，被畫は最 も深刻である ${ }^{23)}$. そして，各集落の中核をなす農民 的小経営階層（B層）は，その営む小商品生産の基 盤の脆弱さが贸害によつて露呈され，その中でも特 に経営の弱体なもの（B C 層）が半プロ層へ転落の 形勢を見せている。つまり被害の重圧は半プロ層お よび転落層の上に集中的にかかつているのである.

このような被害の階層性は，いずれの集落にも貫 徹する基本的傾向であるが，その具体的な現われか たは地域によつて必ずしも同様ではない. 商業化の 点では高度の進み方を示していても，それ自体に前 期的な性格を強く内包するわさび田経営の $\mathrm{J}$ 集落の 場合，および零細商品生産で兼業化の傾斜の強い $\mathrm{O}$ 集落の場合には，被害の階層性は，かなり鋭く現わ れて打り, 半プロ層, 転落層などの下層農家は, 全 く惨めな状態に追込まれている。これに対して，下 流のN集落は農民的経営の発屋が相対的に進んでい るだけに，被害は被害として受けながらも，これを 乗越えるためのつぎのステップを着実に踏み出すだ けの余裕を示している. 破堤部の $\mathrm{S}$ 集落はほとんど 潰隇的な被害をうけながら，共同化の力によつてか

22）破堤部における被害の強烈さは $\mathrm{S}$ 集落の例に見られる通りであるが，この堤防は戦後の新設のもので， それまでは洪水は乗越えるが，決して破堤しない水防林つきの旧堤が明治以来ここにあつた.この旧堤は 高さ $1.5 \mathrm{~m}$ ， 巾 $6 \sim 7 \mathrm{~m}$ の低いもので，密生した竹林に覆われ，前後に桑畑の带をもち堤内の水田を保護 していた・とくに集落前面の水衝部は石積工で固めて溢流に備え，また内側には堤沿いに用水路があつて 乗越えた洪水はこれに沿つて走らせ，水田地带に拡散させるようになつていた。（白山堂 勝村金太郎・ 土屋清四郎両氏談，および同集落保管古図による).

23）われわれの調査は昼間の訪門による聞取調查という制約のため，とくにこの半プロ層の実状についての 把握は極めて不充分である. 
ろうじて転落の危機克服に向つているのは注目に值 する.こうした現状に見るかぎり，下流 2 集落では， 被害の階層性は上流の 2 集落にくらべてそれほど鋭 い形では現われていない.しかし，これは階層性が 存在しないのではなくて，むしろそれが潜在してい るむのと見るべきであろう，なぜならば，現状のよ うな被害の復旧過程の段階ではともかく，それから 先の生産力展開の時期には, 個別経営の資本蓄積の 差がいつそうものを云うようになるのは必然的であ り，今回の災害の影響がその時期になつて階層差を 顕在化させる可能性も決してないとは言えないから である、このように，被害は農業構造の弱点をねら つて集中的に発現しているが，それは地主的支配の
残存, 農民的商品生産の未発達, 半プロ層の下層沈 澱といつた社会的諸条件によつてよりいつそう深化 され，鋭い階層性を示すとともに，それによつて農 業構造の孕む矛盾を拡大し再生産して行く．しかし ながらまた同時にそうした諸関係の下で，漸次的な がらも前進しつつある農業生産力の担当者たる農民 層の成長こそが，被害の克服，災害からの復興のた めの最も基本的な原動力であり，なによりも不可欠 な主体的条件であることを見落してはならないので ある・

この調查にあたつて明大地理学研究会に属する多数の学生諸君の 協力を得た。 また本報告の図表作成に際しては，同会の河田・中川・ 野村・降旗の 4 君に多大の嗳助を得た。ここに記して謝意を表する。

\section{THE STRUCTURE OF THE RURAL SETTLEMENTS DAMAGED BY THE KANOGAWA TYPHOON \\ Motosuke ISHII}

In the Kanogawa river basin, various sorts of commercial agriculture are highly developed, such as strawberry, eutrema wasabi, tobacco, dairy milk, sericulture, etc. other than rice production. The flood by the Kanogawa Typhoon brought about severe damage on the agricultural production in this basin. The author interviewed 71 farmers at four rural settlements $(\mathrm{J}, \mathrm{O}, \mathrm{S}, \mathrm{N})$ located at the upper, middle, and lower parts of the flooded area, and asked them about real status of the dmage and their way of living since the accident.

The influences of the damage on the individual farms are different by the size of the farms and their social classes.

1. Landlord class (class A) : Many of them avoided damages, because of their monopolistic ownership of safty land.

2. Upper class farmers (class B) and part-time farmers (class D) : They overcomed their damages through their own economic potentialities.

3. Lower class farmers (class BC) and part-time farmers (wage earners) (class C) : The degree of their damages was rather high and the effects were very severe. Consequently, many of BC class farmers are going to fall down to the unstable worker-peasant class.

As for the regional difference of the restoration from the damage, settlement of higher standard's agricultural production (settlement $\mathrm{N}$ ) is rather active. In the settlement $\mathrm{S}$ severely damaged by the collapse of dykes, joint cooking and reconstruction for the damage were successfully carried out. 